\title{
LUT
}

University

Coping with rivals' absorptive capacity in innovation activities

Hurmelinna-Laukkanen Pia, Olander Heidi

This is a Final draft version of a publication

published by Elsevier

in Technovation

DOI: $10.1016 /$ j.technovation.2013.07.005

Copyright of the original publication: (c) Elsevier 2013

Please cite the publication as follows:

Hurmelinna-Laukkanen, P., Olander, H. (2014). Coping with rivals' absorptive capacity in innovation activities. Technovation, vol. 34, issue 1. pp. 3-11. DOI: 10.1016/j. technovation.2013.07.005

This is a parallel published version of an original publication. This version can differ from the original published article. 


\title{
Technovation
}

Volume 34, Issue 1, January 2014, Pages 3-11

\section{Coping with rivals' absorptive capacity in innovation activities}

Pia Hurmelinna-Laukkanen ${ }^{\mathrm{a}}$

Heidi Olander ${ }^{\mathrm{b}}$

a Oulu Business School, University of Oulu, Oulu, Finland

${ }^{\mathrm{b}}$ School of Business, Lappeenranta University of Technology, Lappeenranta, Finland

Available online 21 August 2013.

https://doi.org/10.1016/j.technovation.2013.07.005

\begin{abstract}
Two factors jointly determine the likelihood of a firm's competitors obtaining information on its intangible assets and using it to damage the firm's innovation performance. Those factors are the absorptive capacity of the rival firm and the appropriability regime of the innovating firm. However, the precise roles of the two factors in affecting performance outcomes are not well documented. Furthermore, we lack knowledge of the interplay between an appropriability regime and absorptive capacity, although they clearly have the capacity to exert positive and negative effects both on each other and on innovativeness. This study presents findings derived from theoretical discussion and an empirical examination of 155 firms that suggest that while competitors' absorptive capacity does not play a direct negative or positive role on the innovation performance of a firm, an appropriability regime exerts a strong positive influence. Nevertheless, high rival absorptive capacity is not without importance, since the significant interaction effects suggest that a strong appropriability regime has positive effects on innovation performance especially in the context of a rival having high absorptive capacity.
\end{abstract}

Keywords: Innovation performance; knowledge protection; appropriability regime; rival absorptive capacity.

\section{Introduction}

While the innovation performance of a firm overall depends on a variety factors such as R\&D intensity and absorptive capacity of the firm (Cohen and Levinthal, 1990), or breadth of collaboration 
(Laursen and Salter, 2006), it also is very likely to be affected if its management perceives its rivals to have the capability to capture and utilize information about the firm's innovations in a manner that can jeopardize the innovator's competitive advantage (Arrow, 1962; De Bondt, 1996; Knott et al., 2004;). The extent of the threat will be determined by the absorptive capacity of competitors and the strength of the appropriability regime of the innovating firm (Hurmelinna-Laukkanen and Puumalainen, 2013). A firm's appropriability regime comprises the set of mechanisms that protects its innovations from imitation and allows efficient commercial exploitation of them (e.g., intellectual property rights, tacitness, knowledge concealment). If that set of mechanisms is weak, and if rival organizations have a highly developed capability to absorb knowledge assets, the innovating firm faces the risk of losing its core knowledge assets and the commercialization race. When managers perceive their firms' innovations to be in jeopardy, they may be reluctant to invest heavily in innovation activities (Liebeskind, 1996; van Dijk, 2000). However, the situation might not be so clear cut, as both appropriability regimes and a rival having strong absorptive capacity may both benefit a firm's innovativeness and constrain it.

The combination of an appropriability regime and competitors' absorptive capacity, also referred to as expropriability, (Hurmelinna-Laukkanen and Puumalainen, 2013; Knott et al., 2004) has rarely been explicitly addressed in managerial practices or academic studies. Some research has shed light on the joint effects and roles of these determinants of the shape of knowledge flows (e.g., Arbussà and Coenders, 2007; Cassiman and Veugelers, 2002; Escribano et al., 2009; Hurmelinna-Laukkanen and Puumalainen, 2013; Nieto and Quevedo, 2005), but how they interact is still unclear. Yet, a firm that could comprehend these relationships would be equipped to construct an appropriability regime tailored to fit the absorptive capacity of its competitors, which could significantly improve its innovation outcomes.

It seems particularly worth examining the push-and-pull effects of a rival firm's absorptive capacity and an innovating firm's appropriability regime. Both determine knowledge flow and can make innovation more or less attractive, depending on their strength and on their contribution to the delivery of strategy. For example, a firm might react to perceiving its rival as having a high absorptive capacity by curtailing its innovation activities for fear of losing the knowledge generated (meaning that the firm is pulled away from innovating in areas where competitors illustrate high 
levels absorptive capacity), but on the other hand, it might also react by doubling its efforts to continuously innovate to stay ahead of the competition (i.e., the rival's absorptive capacity pushes the firm to innovate more). Similar effects are related to appropriability regimes, as strong protection may push firms to innovate through enabling safe knowledge transfer and increasing expectations on returns, or they might pull firms from innovation if knowledge transfer is hampered within the firm and from external sources or if focus turns to exploitation instead of exploration. To date, little evidence has been presented on the push-pull issues.

Prior research has covered both appropriability and absorptive capacity areas extensively, albeit separately. For example, Lane et al. (2006) analyzed 289 journal articles on absorptive capacity, and covered only a fraction of the studies on the topic. There is less material on appropriability regimes specifically (examples include Hurmelinna-Laukkanen and Puumalainen, 2007; Teece, 1986,1998), but a considerable body of literature can be found on knowledge-protection practices and strategies (e.g., Cohen et al., 2000; Knight, 2001; Levin et al., 1987; Liebeskind, 1996,1997; Neuhäusler, 2012; Pitkethly, 2001; Spencer, 2003).

However much been written on absorptive capacity, it has rarely been scrutinized in the form of competitor capability, as the innovating firm's point of view has dominated. Likewise, the challenge with appropriability related studies has been that they have examined only a single or a few appropriability mechanisms at a time (consider the vast amount of patent strategy literature, for example), or that they have viewed the strength of an appropriability regime as an external, environmental factor that firms react to rather than as a mechanism that firms have the power to construct (see, e.g. Teece, 1986; Volberda et al., 2010). Those few studies that have started to examine the joint effects of an appropriability regime and competitors' absorptive capacity have not yet fully covered the roles and interplay of those factors; a situation exemplified by the somewhat contradictory findings advanced regarding possible interactions (Peters and Johnston, 2009; Todorova and Durisin, 2007).

This study addresses this gap in the prior literature as it examines the kinds of push-and-pull effects on innovation that relate to the absorptive capacity of competitors and the appropriability regime of a firm. The study aims to cover the roles and interaction effects of the two factors, taking as 
its foundation the research question: What are the effects of the strength of an appropriability regime and perceived absorptive capacity on the innovation performance of a firm?

In the following sections, the absorptive capacity of competitors is examined first, followed by a discussion of appropriability issues. Then these factors are considered together, first theoretically, and then in an empirical examination. Discussions of the findings, managerial implications, limitations of the study, and suggestions for future research conclude the paper.

\section{Rival absorptive capacity and innovation performance of a firm - downsides and benefits}

Absorptive capacity (Baranson, 1970; Cohen and Levinthal, 1990) can be defined as a firm's ability to learn from others and is largely based on its prior knowledge. Innovating firms operating in the current competitive and collaborative business environment that develop their absorptive capacity can certainly benefit, but inevitably, the greatest benefits will accrue to those with the most developed absorptive capacity.

Facing rivals with highly developed absorptive capacity may have some notable downsides for an innovating firm (Heiman and Nickerson, 2004; Willman, 1992; Ritala et al., 2009; Saviotti, 1998). That rival firm would be likely to beat its competitors in the learning game, and consequently stay ahead of the competition. Such a situation is likely to reduce the innovating firm's profit margins as competitive or superior products and services emerge into its market. The issue becomes more serious still if the innovating firm loses its core knowledge assets relating to products, processes, and customers to a competitor with a highly developed absorptive capacity and the capacity to apply the knowledge it captures. In that case, there is a very real danger to the innovating firm's competitive position. In addition, incentives to innovate may diminish, as the rival could absorb knowledge about new innovation and employ it commercially more quickly than the innovating firm itself. Bönte and Keilbach (2005) have noted that in decision making on engaging in collaborative activities, the benefits derived from incoming knowledge seem to be outweighed by the ability to prevent outbound knowledge spillovers - especially with regard collaboration with competitors (Ritala et al., 2009); the same applies to competitive settings and innovation activities too (De Bondt, 1996). The perception within an innovating firm that rivals have highly developed rival absorptive capacity might be enough 
to cause it to limit its innovative efforts, making advantageous profit margins less attainable. Laroche and Nioche (1994) for example, consider strategic choices to be built on relatively stable beliefs that are considered to be true.

However, a highly developed absorptive capacity among competitors need not necessarily stifle innovation; in fact, it could deliver benefits. As noted earlier, intensely competitive situation may push a firm to be innovative and compete through continuous development of new and improved products and services, thus increasing the innovation performance of the firm. This may be particularly relevant among internationalized firms (see Autio et al., 2000). An increased level of competition with innovative rivals could also benefit a firm, assuming the firm itself had a relatively higher absorptive capacity and was able to absorb new knowledge from competitors with new innovations; While the firm cannot control the level of its competitors' absorptive capacity, it can make an effort to improve its own capabilities through allocating resources to internal research and development $(\mathrm{R} \& \mathrm{D})$ and through creating good connections to external actors and knowledge sources, including its competitors (Cohen and Levinthal, 1990; Dierickx and Cool, 1989; Lim, 2009). Meaningful competition with rivals may also help to create the critical mass (Lieberman and Montgomery, 1998; Ritala and Hurmelinna-Laukkanen, 2009) necessary to attract the attention of potential customers and end-users. Customers may be more eager to buy products/services that have some competing counterparts (Conner, 1995; Ritala and Hurmelinna-Laukkanen, 2009). In addition, interest from other firms within the same industry can enhance the success of a complex technical product from an innovative firm; for example, it may be necessary to ensure that other companies are able to absorb at least some information so they produce complementary products and support services that boost sales of the core product or service (De Castro et al., 2008; Harhoff et al., 2003; Hurmelinna et al., 2007).

Although rival absorptive capacity — or the perception of it — may have divergent effects on the innovation performance of a firm, it has to be acknowledged that a firm can have but a limited effect on its competitors' capabilities in one direction or another. It can provide better conditions for the potential absorptive capacity of rivals by making relevant information available for them (see Zahra and George, 2002, for the distinction between potential and realized absorptive capacity), but the benefits of doing so may be questionable. With few exceptions (see, e.g. Brandenburger and 
Nalebuff, 1995, 1996 on coopetitive arrangements and De Castro et al., 2008 on potential benefits of piracy), there are considerable risks related to providing competitors with access to innovation-related knowledge. Depending on the individual appropriation and value-capture potential of the rival firm, imitation —or the threat of it - is likely to limit investment in R\&D and innovativeness (Liebeskind, 1996). Accordingly, the following hypothesis is proposed:

H1: Rivals' absorptive capacity is negatively related to the innovation performance of a firm.

\section{Performance effects of appropriability regimes}

The appropriability regime of a firm, which protects innovations and intangible assets, can comprise a range of mechanisms of varying formality. Intellectual property rights (IPRs) (Winter, 2006), contracts (York, 1998), and labor legislation (Hurmelinna-Laukkanen and Puumalainen, 2007) are formal mechanisms with institutional, statutory basis and enforcement possibilities, while lead time (Lieberman and Montgomery, 1998), human resource management (HRM) (Boxall, 1998; Liebeskind, 1996), practical or technical means of concealment (Hurmelinna-Laukkanen and Puumalainen, 2007), and the tacit nature of knowledge (Polanyi, 1966) exemplify informal mechanisms. For example, the protective side of HRM practices becomes visible when a firm offers share options, learning opportunities, and maps out career paths and similar incentives to retain key employees and the knowledge they possess, tacitness protects knowledge by making it inherently sticky, lead time increases causal ambiguity connected to continuous development, and technical concealment restricts access to relevant knowledge (e.g., Hurmelinna-Laukkanen and Puumalainen, 2007; Liebeskind, 1996).

The individual mechanisms are quite different from one other, and therefore, it is the entity generated by them that is relevant. Even country or industry differences (often brought up in prior research viewing an appropriability regime as a macro-level environmental factor; see, e.g., Arbussà and Coenders, 2007) may fade to some extent when the appropriability regime is investigated as a whole. Although there are certainly notable differences regarding, for example, the availability and strength of IPRs across industries and countries, other, informal, mechanisms may be used to compensate for shortcomings in the protective power of the formal mechanisms (Ritala et al., 2009). 
Another point worth noting is that although having strong protective cover in place for innovations does not mean that the competitive situation of the firm is necessarily improved, doing so can be valuable as it enables the firm to decide when to deploy protective power to curtail knowledge flows and when to use appropriability mechanisms to control them instead (Hurmelinna-Laukkanen, 2009). While prior studies have mostly treated the appropriability regime as an external factor that the firm only reacts to (or at best, mostly reacts to), the decisions made within firms are also influential, and the constituent elements of the appropriability regime may be used as tools to achieve a firm's strategic goals (Hurmelinna-Laukkanen and Puumalainen, 2007; Pisano, 2006). In fact, for example Spencer (2003, p. 217) has stated that “some researchers have identified a firm's ability to protect its knowledge from appropriation by rivals as one of the most critical capabilities that it can develop (Liebeskind, 1996, 1997)." The benefits of having a sufficiently strong appropriability regime arise from gaining a temporary monopoly position with higher profit margins, opportunities for customer lock-in, improving the image of a firm by portraying it as operating in the vanguard, and possibly gaining ancillary revenues from licensing and other such activities, which can, for example, be used to fund further innovation (Hurmelinna et al., 2007). Thus, innovativeness is likely to be preserved and fostered by a strong appropriability regime (Liebeskind, 1996).

However, strong regimes do carry risks. When the firm's operations emphasize the protective aspect (Hannah, 2005; Hurmelinna et al., 2007) or when there is a very strong IPR regime in the industry in which the firm operates (Dosi et al., 2006), innovation performance may be restricted. This is because knowledge flows may not be strong enough to promote new combinations of intangibles and subsequent innovations (Crossan and Inkpen, 1995). Furthermore, a litigious firm may acquire a negative image, for example, if the firm is seen as creating unnecessary problems within the industry through its aggressive intellectual property (IP) policy. In some industries, firms must constantly be wary of infringing on their rivals' intellectual property. Creating and maintaining an appropriability regime that is wide and strong enough requires substantial resources, even just to stay on the safe side (i.e., to create space for safe operation without fear of infringements). On the other hand, it may be that if the firm has only limited resources and it puts too many resources into protection, it will not be able to augment its other innovation-related activities, like internationalizing efficiently (see Kuemmerle, 1999; Pla-Barber and Alegre, 2007; Schultz and Nill, 2002). 
Even with the above-mentioned downsides of protection, it is likely that a firm with a sufficiently strong and broad appropriability regime will succeed. A firm able to adjust its appropriability regime to its advantage can turn downsides into benefits. The firm does not necessarily have to use its appropriability mechanisms for protective purposes, as they can be applied to facilitate planned knowledge flows that are far more likely to deliver positive innovation performance than negative performance. The following hypothesis captures this idea:

H2: A strong appropriability regime is positively related to the innovation performance of the firm.

\section{Expropriability determining the level of imitability}

The levels of absorptive capacity possessed by rivals and the strength of a firm's appropriability regime jointly determine the extent of expropriability - the degree to which competing companies can extract information about an innovation and use it for their own purposes, to cause the competitive advantage of the original innovator to be eroded (Greenhalgh and Rogers, 2004; HurmelinnaLaukkanen and Puumalainen, 2013). Strong expropriability describes a situation when the innovating firm has a weak appropriability regime and its rivals have highly developed absorptive capacity. Therefore, strong expropriability equates to a poor innovation position for the focal firm. In the case of weak expropriability (i.e., low levels of absorptive capacity in the rival and a strong appropriability regime) the situation is reversed. Intermediate conditions also exist, so for example, the leading position of the focal firm might be preserved despite it having a weak appropriability regime if rival firms are not able to capture, absorb, and internalize the firm's knowledge.

Prior research has addressed expropriability issues with appropriability and rivals' absorptive capacity combined to a limited extent, and the interaction between the two factors still merits examination, especially considering the managerial implications involved. For example, it is not logical to allocate too many resources to costly protection activities if competitors are unlikely to comprehend the innovation and its underlying ideas. In fact, the act of protecting knowledge assets might even reveal some information to rivals. An example would be when a patent application signals 
the importance of certain knowledge and the direction a firm is heading (Horstmann et al., 1985; Somaya, 2003). Any such signal increases the risk of imitation.

While there may be various ways in which rival absorptive capacity and an appropriability regime are connected (see, e.g., Todorova and Durisin, 2007), little empirical evidence exists on the topic, and measures and other such issues are still developing (see, e.g., Hurmelinna-Laukkanen and Puumalainen, 2013). Therefore, we adopt an exploratory approach to investigate how the two factors interact with respect to the innovation performance of a firm. It has been suggested above that a rival's absorptive capacity can both push firms to innovate or reduce the incentive to do so. An appropriability regime might also have two-directional effects, although it seems more likely that positive effects emerge, especially as the appropriability regime can be manipulated by the firm (and much more easily so than a rival's absorptive capacity). Considering a situation where the absorptive capacity of competitors is low, the positive effects of an appropriability regime on innovation performance might be less obvious than if a rival has high absorptive capacity. The mechanisms used by a firm to limit excessive imitation should be stronger if competitors were originally able to capture part of the innovation-related rewards. Besides, in a situation marked by high competitive pressure, the firms might be forced to innovate, and in such a case, success might follow from a strong appropriability regime. Thus, a moderating effect is likely to emerge:

H3: The level of evaluated rival absorptive capacity moderates the relationship between the strength of the appropriability regime and innovation performance.

\section{Empirical examination}

\section{Sample and data collection}

The data used in this study was collected in Finland in 2008 and 2009 with a structured, web-based questionnaire, using the key-informant technique. The risk of common method variance was addressed by application of the suggestions of Podsakoff et al. (2003). The original population covered a cross-industry sample of Finnish companies engaged in R\&D (i.e., firms with ongoing R\&D and innovation activity and an opportunity to influence such activity autonomously) and with at 
least 100 employees. These selection criteria led to identifying 762 companies from the Amadeus database. The firms were contacted first by telephone in order to assess their eligibility, identify suitable respondents, and inquire if they were willing to participate. Confidentiality was emphasized, and a summary of results was promised to respondents. Of the $762 \mathrm{R} \& \mathrm{D}$ representatives, researchers had reached 570 after several contact attempts. Following this initial telephone contact, 115 people declined to participate Questionnaires were submitted by 213 companies, ensuing an initial response rate of 37.4 percent, but four were later rejected when it became apparent that the firms did not employ at least 100 people, resulting in a final sample size of 209 firms. Limiting the analysis further to companies with international activity (155 firms) was done to improve the generalizability of the results. In particular, as internationalization exposes firms to higher levels of competition, it is more likely that these firms have evaluated competitors and the effects of imitation more analytically (Autio et al., 2000; Liebeskind, 1996). The firms are also likely to face similar conditions governing the need to build strong appropriability regimes. Of the 155 firms, $38 \%$ operated in manufacturing sector, $25 \%$ in machinery and vehicles, $14 \%$ in information and communications (ICT) and electronics sector, $8 \%$ in trade and transport, $4 \%$ were focused on construction and infrastructure, and $11 \%$ were service companies. Most respondents held positions such as R\&D manager, development officer, chief executive officer, or managing director, indicating their key position in terms of $\mathrm{R} \& \mathrm{D}$ and innovation.

Non-response bias was checked using the analysis of variance (ANOVA) test, following the suggestions of Armstrong and Overton (1977). Five factors were selected to assess the existence of bias: ROCE 2007 (Return On Capital Employed, public data); Sales 2007 (public data); number of employees 2007 (public data); market performance 2009, adapted from Delaney and Huselid (1996); and innovation performance 2009, adapted from Alegre and Chiva (2008). No signs of non-response bias were found. 


\section{Dependent variable}

The measure for innovation performance was adapted from those of Alegre et al. (2006) and Alegre and Chiva (2008). Seven items covering replacement of products and services being phased out, extension of product/service range within and outside main market, development of environmentfriendly products/services, and opening of new markets abroad and for new domestic target groups were included in the measure (INNO_PERF; see Appendix). A seven-point Likert scale was used. The Cronbach's alpha value was .792.

\section{Independent variables}

Two multi-item sets were used to measure the strength of the appropriability regime and the level of evaluated rival absorptive capacity for each firm. Both explanatory variables were normally distributed.

Regarding the strength of the appropriability regime, various protection mechanisms were covered, following the examples of the Yale (Levin et al., 1987) and Carnegie Mellon (Cohen et al., 2000) surveys and subsequent augmentations (e.g., Hurmelinna-Laukkanen and Puumalainen, 2007). An explorative factor analysis (principal component analysis with Varimax rotation) was first conducted to see how the numerous appropriability items (measured on a seven-point Likert scale) loaded on different factors. Seven factors emerged (see Appendix), each representing different mechanisms. The mean scores of the seven factors were then combined in order to obtain the overall score (mean) for appropriability strength (APPRO_REG). The Cronbach's alpha was above the suggested threshold level of 0.70 (see Nunnally, 1978) for each of these factors, and the alpha value for the final measure was .755.

The perception of rival firm's absorptive capacity was assessed through ten items built on the theoretical discussion in Zahra and George (2002) and each measured on a seven-point Likert scale. There are various ways of measuring absorptive capacity, such as using $R \& D$ expenses or number of patents as the proxy (Cohen and Levinthal, 1990; Gambardella, 1992; George et al., 2001), or defining it as "pre-alliance levels of technological overlap among the partners" (Mowery et al., 1996, 
p. 81), or measuring it in terms of employee ability and motivation (Minbaeva et al., 2003; Tu et al., 2006), or as competitor's awareness and learning capability of the innovating firm's development activities (Hurmelinna-Laukkanen and Puumalainen, 2013). In this study, respondents were asked to assess their perceptions of their competitors' firm-specific inclination to acquire and use knowledge, an approach Kumar et al. (1993) confirm to be useful. Items used to create the measure for evaluated rival absorptive capacity (eRIVAL_ACAP) are shown in the Appendix. The Cronbach's alpha for the measure was .948 .

\section{Control variables}

Age, size (measured as the number of personnel in 2007), R\&D intensity, and the share of turnover derived from foreign markets were controlled for. Age and size have been identified as factors to be taken into account when assessing innovation performance (Chandy and Tellis, 1998; Huergo and Jaumandreu, 2004; Laursen and Salter, 2006), and R\&D intensity may very well contribute to innovation outcomes. However, findings on the subject are not uniform as for example, Laursen and Salter (2006) report a positive relationship, and Hall and Bagchi-Sen (2002) and Blonigen and Taylor (2000) question whether such a relationship exists. Finally, the degree of internationalization has been said to influence a firm's potential to acquire valuable new knowledge and learning opportunities (Baughn et al., 1997; Chesbrough, 2003; Lu and Beamish, 2001), and therefore, we control for the share of turnover coming from abroad. Although examining appropriability regime as a whole very likely makes industry differences regarding strength of protection and appropriation less pronounced (as noted above, equal strength for the appropriability regime can be achieved with different aggregations of individual mechanisms), we acknowledge the possibility of differences, and therefore industry effects were also controlled for with a set of dummy variables, with manufacturing as the base condition.

\section{Analyses and results}

Given that the data used in this study were collected from a single informant in each organization at a given point in time, the problem of common method variance could potentially have affected the results, even if procedural remedies suggested by Podsakoff et al. (2003) were applied. Therefore, 
following the example of Podsakoff et al. (2003), Harman's one-factor test was first used in order to assess the risk. An explorative factor analysis was conducted in which all the continuous variables were inserted. The largest factor that emerged accounted for only 18 percent of the variance, and consequently, we can claim with confidence that common method variance bias does not jeopardize the results.

Table 1 illustrates the descriptive statistics and presents the correlation matrix. The mean values and standard deviations of age, size, R\&D intensity, and DOI suggest that they present certain issues of skewness. Consequently, logarithmic transformations were used in the analyses. Rival absorptive capacity and the appropriability regime are perceived generally to be rather high, as is innovation performance.

The correlation matrix was used to make an initial assessment of the hypothesized relationships. An appropriability regime seems to have a positive effect on innovation performance, while the negative relationship between evaluated rival absorptive capacity and innovation performance is not statistically significant. The two explanatory variables are not related to each other either. R\&D intensity is positively related to the appropriability regime strength and negatively related to age of the firm. It was slightly surprising to see that DOI is negatively related to innovation performance. Investigating the reasons is beyond the scope of this study, but it may be that high DOI indicates a focus on exploitation to the detriment of exploration by the respondent firms.

Table 1

Descriptive statistics and Pearson correlation matrix.

\begin{tabular}{|c|c|c|c|c|c|c|c|}
\hline & Mean (St.d.) & 2 & 3 & 4 & 5 & 6 & 7 \\
\hline 1 inno_perf & $4.67(.934)$ & -.060 & $.262^{* * *}$ & -.073 & .121 & .066 & $-.153^{b}$ \\
\hline 2 eRival_acap & $4.37(1.068)$ & 1.00 & .030 & .040 & .067 & .111 & .133 \\
\hline 3 appro_reg & $4.19(1.396)$ & & 1.00 & .012 & -.140 & $.188^{*}$ & .114 \\
\hline 4 age $^{\mathrm{a}}$ & $20.5(21.69)$ & & & 1.00 & .000 & $-.150^{*}$ & -.114 \\
\hline 5 size $^{a}$ & 1334 (3889.9) & & & & 1.00 & -.103 & .026 \\
\hline 6 R\&D_int ${ }^{3}$ & $4.45(12.2)$ & & & & & 1.00 & .124 \\
\hline $7 \mathrm{DOI}^{\mathrm{a}}$ & $10.21(7.40)$ & & & & & & 1.00 \\
\hline
\end{tabular}

Notes:

a Logarithmic transformations were used in the analyses to correct for skewness.

b $p<.10$ actual values are presented in the descriptive statistics.

* $p<.05$ actual values are presented in the descriptive statistics.

$p<.01$ actual values are presented in the descriptive statistics. 
To test the hypotheses, linear regression analysis was applied. We conducted basic tests preceding regression analysis. Logarithmic transformations were used for correcting skewness of variables when necessary. The values of the variable inflation factor (VIF) scores were under two, and thus multicollinearity was not a problem (see Hair et al., 1998). There was no evidence of heteroscedasticity when examining the residuals, nor problems with autocorrelation. The $\mathrm{R}^{2}$ for Model 2 was rather low. However, after checking the plots for residuals (mean equals to zero and the distribution is normal), we did not see obvious problems with regard specification bias, for example. The results are presented in the Table 2. First, control variables were entered in the analyses (Model 1); then the dependent variables were included to examine Hypotheses 1 and 2 (Model 2); and finally the interaction term was added in order to find out whether moderating effects suggested in $\mathrm{H} 3$ exist (Model 3).

Table 2

Linear regression analyses.

\begin{tabular}{llll}
\hline Dependent variable: Inno_perf & Model 1 & Model 2 & Model 3 \\
\hline age $^{\mathrm{a}}$ & $-.083(.11)$ & $-.085(.10)$ & $-.073(.10)$ \\
size $^{\mathrm{a}}$ & $.146(.07)$ & $.192^{*}(.07)$ & $.211^{*}(.07)$ \\
R\&D_int $^{\mathrm{a}}$ & $.076(.07)$ & $.027(.07)$ & $.030(07)$ \\
DOI $^{\mathrm{a}}$ & $-.196^{\mathrm{b}}(.08)$ & $-.225^{*}(.08)$ & $-.216^{*}(.08)$ \\
Machinery\&Vehicles $_{\text {ICT\&Electronics }}$ & $.119(.24)$ & $.130(.23)$ & $.138(.23)$ \\
Wholesale\&Retail & $.024(.29)$ & $.071(.28)$ & $.095(.28)$ \\
Construction\&Infrastructure & $-.036(.35)$ & $.039(.34)$ & $.041(.34)$ \\
Services & $.023(.32)$ & $.019(.47)$ & $.002(.46)$ \\
eRival_acap & & $-.018(.32)$ & $.026(.32)$ \\
appro_reg & & $.315^{* \neq}(.06)$ & $.317^{* *}(.06)$ \\
approXeRacap & & & $.249^{*}(.14)$ \\
$R^{2}$ & .071 & .016 & .204 \\
$F$ & .840 & 1.679 & 2.048 \\
$F$ change & & $5.136^{* *}$ & $5.287^{*}$ \\
\hline
\end{tabular}

Notes: Standard errors in parentheses.

a Logarithmic transformations were used in the analyses to correct for skewness.

${ }^{\mathrm{b}} \mathrm{p}<.10$.

${ }^{*} p<.05$.

*** $p<.01$.

The results of the regression analyses confirm what was seen in the correlation matrix: while appropriability strongly and positively affects innovation performance-supporting Hypothesis 2the perceived level of absorptive capacity of a rival does not seem to play such a pronounced role. Thus, despite the negative sign, Hypothesis 1 is not supported. 
Support was found for Hypothesis 3; as the interaction term turned out to be moderately significant. In order to establish the nature of the interaction, the effects of appropriability regime strength were plotted for given values of evaluated absorptive capacity among rivals, as suggested by Cohen et al. (2003). The high and low values were set at one standard deviation above and below the mean. A range of values for the strength of the appropriability regime was used to compute values for the dependent variable (innovation performance) based on the unstandardized regression coefficients. The findings are presented in Figure 1.

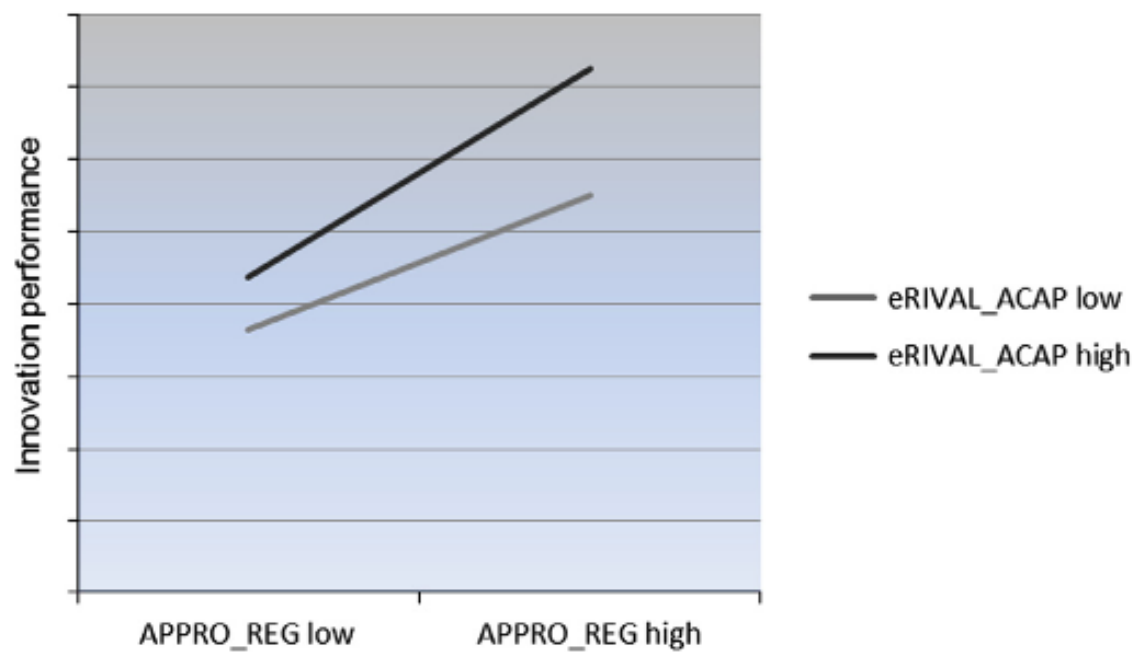

Fig. 1. Effect of the appropriability regime: rivals' absorptive capacity interaction on innovation performance of a firm.

The figure illustrates that while the appropriability regime yields positive results in terms of innovation performance in any case, the positive effects are particularly notable in cases when the perception is that rivals have highly developed absorptive capacity. The reasons behind this and other findings are discussed in the following section.

\section{Discussion}

Our aim in this study was to answer the question: What are the effects of the strength of an appropriability regime and perceived absorptive capacity on the innovation performance of the firm? The empirical findings presented indicate that an appropriability regime plays a notable role in the innovation activities of a firm. As noted in the theoretical discussion, an appropriability regime not 
only promotes innovation performance by allowing knowledge exchange to occur to the benefit of new innovation but can generate monetary resources to fund expensive $R \& D$ activities. Appropriability mechanisms can also incentivize innovation, by allowing the firm room to decide what to do with new creations and how maximize profit from them. However, the role of the absorptive capacity of a rival must also be acknowledged.

We could not find support for our hypothesis concerning the role of the perceived absorptive capacity of a rival on the focal firm's innovation performance, as the negative relationship was not statistically significant. However, this does not mean that a competitor's absorptive capacity is insignificant or is ignored by firms. First, it may be that, as noted in the theoretical discussion in section four, perceptions of a rival's absorptive capacity have two-directional effects on innovation performance. The negative sign might indicate that, originally, a rival's highly developed absorptive capacity can impede innovation (e.g., by inculcating fear of losing profits or intangibles to those rivals) even if the statistical significance disappears due to the positive effects that foster innovation (e.g., the push for innovation and the need to promote critical mass and support services). Furthermore, the interaction term comprising the appropriability regime and rival's absorptive capacity demonstrated statistical significance. It seems that a strong appropriability regime has positive effects on innovation performance especially in the context of a rival having high absorptive capacity. When competitors are perceived to have high levels of absorptive capacity, it pushes the firm to be even more innovative (i.e., the positive effects take over) (see, e.g., Autio et al. 2000). The prerequisite for this positive effect is, however, that the firm can protect its intellectual assets and innovations. When assisted by a strong appropriability regime, innovation activities can be pursued successfully even in a demanding competitive environment. In other words, the combination of strong appropriability and high level of absorptive capacity among rivals seems to be the best in terms of providing incentives to invest in innovation and innovation outcomes. 


\section{Conclusions}

In this study, we have discussed and empirically examined the individual and combined roles of the appropriability regime of a firm and the absorptive capacity of its rivals. There are several areas where this study contributes to current knowledge.

First, as noted in section six, current literature most often addresses appropriability issues and absorptive capacity separately. However, this study, alongside a few other studies (Peters and Johnston, 2009; Todorova and Durisin, 2007) in this area, shows that the interplay between these factors is relevant to a firm's innovation performance.

In addition, in a departure from prior studies, this study concentrated on competitors' absorptive capacity rather than the absorptive capacity of the innovating firm. While perceptions that a firm has about its competitors may not be wholly correct, they might be accurate enough, and they will certainly influence the strategic decisions that the firm takes (Laroche and Nioche, 1994).

Another addition to current knowledge is the idea that in addition to given exogenous (Teece, 1986; Volberda et al., 2010) features affecting the composition of the appropriability regime, it also has endogenous features and that its strength can be adjusted. This is especially relevant for managers tasked with countering competitors' actions and capabilities.

Also, empirical evidence is still scarce, and departing from prior studies, we have tried to develop the measures and the way in which the data is analyzed, For example, in the study of HurmelinnaLaukkanen and Puumalainen (2013), the measure for rival's absorptive capacity was quite different from that of ours that better captures the different dimensions of absorptive capacity. Also, the research setting was different in the sense that in the earlier study the analyses were done through cluster analysis (thereby dichotomizing the variables) and through industry classifications, whereas our approach aims at generating a more holistic picture of the phenomenon.

Dealing with competitors' absorptive capacity—whether actual or perceived—by relying on an appropriability regime is challenging, but when managers get it right, there is considerable potential to reap optimal benefits from innovation activities. Our findings suggest that it is worthwhile to build a sufficiently strong and broad appropriability regime for the firm, especially in a situation where competitors demonstrate a highly developed capacity to absorb knowledge. Once the appropriability 
regime is in place, it can be strategically manipulated according to emerging needs. Certainly, excessive costs must be avoided, but appropriability regimes comprise various mechanisms, some of which have very little associated cost. Managers who are aware of these aspects can improve the innovation performance of their firms by lowering its protective shields slightly and fostering the absorptive capacity of its rivals just enough to create a beneficial level of competition and complementarity within the industry needed to promote the innovation. What is particularly noteworthy is that pursuing a goal of making valuable firm assets completely inimitable might not be the wisest option. It may sound economically logical, but a scenario where rivals retain some absorptive capacity may also be advantageous. A firm that believes its competitors are actively absorbing knowledge for innovation, is likely to strive to improve its own innovative activity.

There are some limitations to this study, for example, regarding the data used. While industry differences are controlled for in this study, examining these issues in different fields of business might offer more information. Likewise, while Finland provides a good environment for studying these issues due to its relatively high innovation rates (Hollanders and Es-Sadki, 2013) and membership in the European Union, it may be that the country-specific features affect the findings. Although we believe that the results are aligned with similar kinds of firms in other Western countries with effective legal systems (in terms of intellectual property protection and competition laws, examining these issues in different countries might be worthwhile. Furthermore, the data has been gathered from single respondents from the companies with single survey, whereas consecutive surveys examining dependent and independent variables would be ideal. The measures could also be developed further so as to better capture causalities and interactions.

Further research is also needed content-wise. Reasons why the absorptive capacity (or the perceived absorptive capacity) of a rival stimulates the effects recorded in this study is one area of future studies. Rival's absorptive capacity can have two-directional effects on innovation performance. As noted in the discussion section, the negative sign might indicate that, originally, a rival's highly developed absorptive capacity can deter innovation, but the statistical significance becomes obsolete when positive effects of the perceived rival's absorptive capacity on innovation are considered. These issues should be examined further. The negative and positive effects could be examined further in qualitative studies, for example. Further research is warranted, especially in terms 
of the interaction between an appropriability regime and a rival's absorptive capacity, as the interaction term exhibited statistical significance. These might be relevant to consider in service- and manufacturing-oriented industries separately, for example. Likewise, issues such as close geographical proximity to competitors (cf., e.g., Alcácer and Chung, 2007), channels of information flows, industrial espionage, and movement of human capital could be examined. In addition, the twodimensional effects of an appropriability regime and its endogenous features merit more attention. Interaction with firm size could be also examined. Finally, a point worth noticing is that we also observe a negative relationship between the share of international turnover and innovation performance. This might indicate that there is a trade-off between innovation and internationalization as growth strategies (see, e.g., Lecerf, 2012). Examining the effects of expropriability on these issues might be an area worth closer examination. Future studies could shed light on these aspects. 


\section{References}

Alcácer, J., Chung, W., 2007. Location strategies and knowledge spillovers. Manag. Sci. 53, 760776.

Alegre, J., Lapierda, R., Chiva, R., 2006. A measurement scale for product innovation performance. Eur. J. Innovat. Manag. 9, 333-346.

Alegre, J., Chiva, R., 2008. Assessing the impact of organizational learning capability on product innovation performance: An empirical test. Technovation. $28,315-326$.

Arbussà, A., Coenders, G., 2007. Innovation activities, use of appropriation instruments and absorptive capacity: Evidence from Spanish firms, Res. Pol. 36, 1545-1558.

Armstrong, J.S., Overton, T.S., 1977. Estimating nonresponse bias in mail surveys. J. Market Res. $14,396-402$.

Arrow, K., 1962. Economic welfare and the allocation of resources for invention, in: Nelson R (Ed.), The Rate and Direction of Inventive Activity: Economic and Social Factors, Princeton University Press: New York. pp. 609-625.

Autio, E., Sapienza, H., Almeida, J.G., 2000. Effects of age at entry, knowledge intensity and imitability on international growth. Acad. Manag. J. 43, 909-924.

Baughn, C.C., Stevens, J.H., Denekamp, J.G., Osborn, R.N., 1997. Protecting intellectual capital in international alliances. J. World Bus. 32, 103-117.

Baranson, J., 1970. Technology transfer through the international firm. Am. Econ. Rev. 60 , 435440.

Blonigen, B.A., Taylor, C.T., 2000. R\&D intensity and acquisition in high-technology industries: Evidence from the US electronic and electrical equipment industries. J. Ind. Econ. 48, 47-70.

Boxall, P., 1998. Achieving competitive advantage through human resource strategy: Towards a theory of industry dynamics. Hum. Resource Manag. Rev. 8, 265-288.

Brandenburger, A.M., Nalebuff, B.J., 1995. The right game: Use game theory to shape strategy. Harv. Bus. Rev. 73 , 57-71.

Brandenburger, A.M., Nalebuff, B.J., 1996. Co-opetition. Currency/Doubleday, New York. 
Bönte, W., Keilbach, M., 2005. Concubinage or marriage? Informal and formal cooperations for innovation. Int. J. Ind. Organ. 23, 279-302.

Cassiman, B., Veugelers, R., 2002. R\&D cooperation and spillovers: Some empirical evidence from Belgium. Am. Econ. Rev. 92, 1169-1184.

Chandy, R.K., Tellis, G.J., 1998. Organizing for radical product innovation: the overlooked role of willingness to cannibalize. J. Market. Res. 35, 474-487.

Chesbrough, H., 2003. The logic of open innovation: managing intellectual property. Calif. Manag. Rev. 45, 33-58.

Cohen, J., Cohen, P., West, S.G., Aiken, L.S., 2003. Applied multiple regression/ correlation analysis for the behavioural sciences, third ed. Lawrence Erlbaum Associates, Mahwah, NJ.

Cohen, W.M., Levinthal, D.A., 1990. Absorptive capacity: A new perspective on learning and innovation. Admin. Sci. Q. 35, 128-152.

Cohen, W.M., Nelson, R.R., Walsh, J.P., 2000. Protecting their intellectual assets: appropriability conditions and why U.S. manufacturing firms patent (or not). Working Paper 7552, National Bureau of Economic Research, Inc.

Conner, K.R., 1995. Obtaining strategic advantage from being imitated: when can encouraging “clones” pay? Manag. Sci. 41, 209-225.

Crossan, M.M., Inkpen, A.C., 1995. The subtle art of learning through alliances. Bus. Q. 60, 6878.

De Bondt, R., 1996. Spillovers and innovative activities. Int. J. Ind. Organ. 15, 1-28.

De Castro, J.O., Balkin, D.B., Shepherd, D.A., 2008. Can entrepreneurial firms benefit from product piracy? J. Bus. Venturing. 23, 75-90.

Delaney, J.T., Huselid, M.A., 1996. The impact of human resource management practices on perceptions of organizational performance, Acad. Manag. J. 39, 949-969.

Dierickx, I., Cool, K., 1989. Asset stock accumulation and sustainability of competitive advantage. Manag. Sci. 35, 1504-1511.

Dosi, G., Malerba, F., Ramello, G.B., Silva, F., 2006. Information, appropriability, and the generation of innovative knowledge four decades after Arrow and Nelson: An introduction. Ind. Corp. Change. 15, 891-901. 
Escribano, A., Fosfuri, A., Tribó, J.A., 2009. Managing external knowledge flows: The moderating role of absorptive capacity. Res. Pol. 38, 96-105.

Gambardella, A., 1992. Competitive advantages from in-house scientific research: The U.S. pharmaceutical industry in the 1980s. Res. Pol. 21, 391-407.

George, G., Zahra, S.A., Wheatley, K.K., Khand, R., 2001. The effects of alliance portfolio characteristics and absorptive capacity on performance: A study of biotechnology firms. J. High Tech. Manag. Res. 12, 205-226.

Greenhalgh, C., Rogers, M., 2004. The value of innovation: The interaction of competition, research \& development and intellectual property. Oxford IP Research Centre, Working papers, EJWP 07/04.

Hair, J.F., Jr., Anderson, R.E., Tatham, R.L., Black, W.C., 1998. Multivariate data analysis, fifth ed. Prentice-Hall, Englewood Cliffs.

Hall, L.A., Bagchi-Sen, S., 2002. A study of R\&D, innovation, and business performance in the Canadian biotechnology industry. Technovation. 22, 231-244.

Hannah, D.R., 2005. Should I keep a secret? The effects of trade secret protection procedures on employees' obligations to protect trade secrets. Org. Sci. 16, 71-84.

Harhoff, D., Henkel, J., von Hippel, E., 2003. Profiting from voluntary information spillovers: how users benefit by freely revealing their innovations. Res. Pol. 32, 1753-1769.

Heiman, B.A., Nickerson, J.A., 2004. Empirical evidence regarding the tension between knowledge sharing and knowledge expropriation in collaborations. Manag. Decis. Econ. 25, 401-420.

Hollanders, H., Es-Sadki, N. 2013. Innovation Union Scoreboard 2013 - The innovation union's performance scoreboard for research and innovation. Maastricht Economic and Social Research Institute on Innovation and Technology (UNU-MERIT). available at: http://ec.europa.eu/enterprise/ policies/innovation/files/ius-2013_en.pdf.

Huergo E., Jaumandreu, J., 2004. How does probability of innovation change with firm age? Small Bus. Econ. 22, 193-207.

Hurmelinna-Laukkanen, P., 2009. The availability, strength and efficiency of appropriability mechanisms - protecting investments in knowledge creation. Int. J. Tech. Manag. 45, 282-290. 
Hurmelinna, P., Kyläheiko, K., Jauhiainen, T., 2007. The Janus face of the appropriability regime in the protection of innovations: Theoretical re-appraisal and empirical analysis. Technovation. 27, $133-144$.

Hurmelinna-Laukkanen, P., Puumalainen, K., 2007. Nature and dynamics of appropriability strategies for appropriating returns on innovation. R\&D Manage. 37, 95-112.

Hurmelinna-Laukkanen, P. and Puumalainen, K. 2013. Innovation performance in the shadow of expropriability-interplay of the appropriability regime and competitors' absorptive capacity. Int. J. Innovat. Tech. Manag. 10, 1, 1-22.

Horstmann, I., MacDonald, G.M., Slivinski, A., 1985. Patents as information transfer mechanisms: to patent or (maybe) not to patent. J. Pol. Econ. 93, 837-858.

Knight, J.H., 2001. Patent strategy for researchers and research managers. John Wiley \& Sons. Ltd. Chichester.

Knott, A.M., Wu, B., Posen, H., 2004. Spillover asymmetry. Paper presented at the Fall Conference, College on Organization Science, 7th November 2004, Tuck School of Business, Dartmouth.

Kumar, N., Stern, L., Anderson, J., 1993. Conducting interorganizational research using key informants. Acad. Manag. J. 36,1633-1651.

Kuemmerle, W., 1999. The drivers of foreign direct investment into research and development: An empirical investigation. J. Int. Bus. Stud. 30, 1-24.

Lane, P.J., Koka, B.R., Pathak, S., 2006. The reification of absorptive capacity: A critical review and rejuvenation of the construct. Acad. Manag. Rev. 31, 833-863.

Laroche, H., Nioche, J-P., 1994. L'approche cognitive de la strategie d'entreprise, Rev. Fr. Gest. 99, 64-79.

Laursen, K., Salter, A., 2006. Open for innovation: The role of openness in explaining innovation performance among U.K. manufacturing firms. Strat. Manag. J. 27, 131-150.

Lecerf, M.-A. 2012. Internationalization and Innovation: The effects of a strategy mix on the economic performance of French SMEs. Int. Bus. Res., 5, 2-13.

Levin, R.C., Klevorick, Alvin K., Nelson, R.R., Winter, S.G., 1987. Appropriating the returns from industrial research and development, Brookings Papers on Economic Activity, 3, 783-831. 
Lieberman, M.B., Montgomery, D.B., 1998. First-mover (dis)advantages: Retrospective and link with the resource-based view. Strat. Manag. J. 19, 1111-1125.

Liebeskind, J.P., 1996. Knowledge, strategy, and the theory of the firm, Strat. Manag. J, 17, 93107.

Liebeskind, J. P., 1997. Keeping organizational secrets: Protective institutional mechanisms and their costs, Ind. Corp. Change. 6, 623-663.

Lim, K., 2009. The many faces of absorptive capacity: Spillovers of copper interconnect technology for semiconductor chips. Ind. Corp. Change. 18, 1249-1284.

Lu, J., Beamish, P.W., 2001. The internationalization and performance of SMEs. Strat. Manag. J. $22,565-586$.

Mowery, D. C., Oxley, J.E., Silverman, B.S., 1996. Strategic alliances and interfirm knowledge transfer. Strat. Manag. J. 17 (Winter special issue), 77-91.

Minbaeva, D., Pedersen, T., Björkman, I., Fey, C.F., Park, H.J., 2003. MNC knowledge transfer, subsidiary absorptive capacity, and HRM. J. Int. Bus. Stud. 34, 586-599.

Neuhäusler, P., 2012. The use of patents and informal appropriation mechanismsm - Differences between sectors and among companies, Technovation, 32, 681-693.

Nieto, M., Quevedo, P., 2005. Absorptive capacity, technological opportunity, knowledge spillovers, and innovative effort, Technovation, 25, 1141-1157.

Nunnally, J.C., 1978. Psychometric Theory. McGraw-Hill: New York.

Peters, L.D., Johnston, W.J., 2009. Understanding absorptive capacity from a network perspective. J. Bus. Market Manag. 3 , 29-50.

Pisano, G.P., 2006. Profiting from innovation and the intellectual property revolution. Res. Pol. 35 , $1122-1130$.

Pitkethly, R.H., 2001. Intellectual property strategy in Japanese and UK companies: patent licensing decisions and learning opportunities. Res. Pol. 30, 425-442.

Pla-Barber, J., Alegre, J., 2007. Analysing the link between export intensity, innovation and firm size in a science-based industry, Int. Bus. Rev. 16 , 275-293. 
Podsakoff, P. M., S. B. MacKenzie, J.-Y. Lee, Podsakoff, N. P., 2003. Common method biases in behavioral research: A critical review of the literature and recommended remedies. J. App. Psy. 88, 879-903.

Polanyi, M., 1966. The Tacit Dimension. Doubleday, Garden City, NY, 1966.

Ritala, P., Hurmelinna-Laukkanen, P., 2009. What's in it for me? Creating and appropriating value in innovation-related coopetition. Technovation. 29, 819-828.

Ritala, P., Hurmelinna-Laukkanen, P., Blomqvist, K., 2009. Tug of war in innovation -coopetitive service development. Int. J. of Serv. Techn. and Manag. 12, 225-272.

Saviotti, P.P., 1998. On the dynamics of appropriability, of tacit and of codified knowledge. Res. Pol. 26, 43-856.

Schultz II, C. J., Nill, A., 2002. The societal conundrum of intellectual property rights. Eur. J. Market. 36, 667-688.

Somaya, D., 2003. Strategic Determinants of decisions not to settle patent litigation, Strat. Manag. J. 24, 17-38.

Spencer, J.W., 2003. Firms' knowledge-sharing strategies in the global innovation system: Empirical evidence from the flat panel display industry. Strat. Manag. J. 24, 217-233.

Teece, D.J., 1986. Profiting from technological innovation: Implications for integration, collaboration, licensing and public policy. Res. Pol. 15, 285-305.

Teece D.J., 1998. Capturing value from knowledge assets: The new economy, markets for knowhow, and intangible assets, Calif. Manag. Rev. 40, 55-79.

Todorova, G., Durisin, B., 2007. Absorptive capacity: Valuing a reconceptualization. Acad. Manag. Rev. 32, 774-786.

Tu, Q., Vonderembse, M.A., Ragu-Nathan, T.S., Sharkey, T.W., 2006. Absorptive capacity: enhancing the assimilation of time-based manufacturing practices. J. Op. Manag. 24, 692-710.

Van Dijk, M., 2000. Technological regimes and industrial dynamics: the evidence from Dutch manufacturing, Ind. Corp. Change. 9, 173-194.

Volberda, H.W., Foss, N.J., Lyles, M.A., 2010. Absorbing the concept of absorptive capacity: How to realize its potential in the organization field. Org. Sci. 21, 931-951. 
Willman, P., 1992. Playing the long game; reaping the benefits of technological change. Bus. Strat. Rev. 3, 89-98.

Winter, S., 2006. The logic of appropriability: From Schumpeter to Arrow to Teece. Res. Pol. 35 , $1100-1106$.

York, T., 1998. Signing the dotted line. Infoworld. $20,128$.

Zahra, S.A., George, G., 2002. Absorptive capacity: a review, reconceptualization, and extension. Acad. Manag. Rev. 27, 185-03. 
Table A1

Measures used.

Innovation performance

How would you compare your organization's performance over the last three years to that of other organizations operating in the same sector?

$(1=$ performed very poorly, $7=$ performed very well $)$

Replacement of products being phased out

Replacement of services being phased out

Extension of product/service range within main market

Extension of product/service range outside main market

Development of environment-friendly products/services

Opening of new markets abroad

Opening of new domestic target groups

\section{Appropriability regime}

During the last three years, how well have the following mechanisms protected your innovations (products, services, processes) from competitor imitation? ( 1 =not applicable to our innovations, $2=$ poorly, $7=$ very well $)$

IPRs (reliability $=.72$ )

Patents

Copyrights

Trademarks

Contracts (reliability $=.75$ )

Long-term collaboration contracts

Non-disclosure/confidentiality agreements

Labor legislation (reliability $=.80$ )

Inter-firm contracts prohibiting recruiting personnel from each other

Employee non-competition agreements

Legal loyalty obligations of employees

Human resource management (reliability $=.76$ )

Getting personnel committed to the firm (e.g., by offering perks)

Low personnel turnover/minimizing it

Secrecy (reliability $=.72$ )

Using passwords

Restricting access to meetings and the firm's premises

Lead time (reliability $=.80$ )

Getting to markets first with a new product or service

Continuous improvements in products/services/processes

Keeping ahead of competitors

Tacitness and complexity of knowledge (reliability $=.89$ )

Complexity of the product/service/process

The fact that it is very hard to teach knowledge related to the product/service/process

The fact that it is very hard to understand the features of the product/service/process by observing/examining it

The fact that knowledge related to the product/service/process may not be usable in other environments

The fact that it is not possible to document knowledge related to the product/service/process

The fact that core knowledge related to the product/service/process is embedded in routines

Evaluated rival absorptive capacity

How well do the following statements characterize your company's competitive environment? $(1=$ totally disagree, $7=$ totally agree $)$

Our competitors have invested heavily in acquiring new knowledge

Our competitors can identify and quickly acquire information they need

Our competitors try to obtain new knowledge as soon as it is available

Our competitors constantly try to increase the number of information sources they have

Our competitors can learn new things effortlessly

Our competitors can easily interpret the information they acquire

Our competitors are good at connecting new and existing knowledge

Our competitors are good at combining information from different sources to their advantage

Our competitors' existing practices make it possible to use new and current capabilities

Our competitors are good at using new knowledge in their operations 